\title{
The Nexus between Co-production and Willingness: Business Counselling in the Microfinance Sector
}

\author{
http://doi.org/10.21272/fmir.4(2).43-51.2020.
}

\section{Ruwan Abeysekera}

Senior Lecturer, Grade 1, Faculty of Commerce and Management Studies, Department of Finance, University of Kelaniya, Sri Lanka, PhD (UK), MBA (Sri Lanka), BSc (Hon) (Sri Lanka), DipM (UK), Kelaniya, Sri Lanka

\begin{abstract}
Microfinance plays a vital role to alleviate poverty through the development of micro enterprises. Microfinance Institutions (MFIs) provide services such as micro credit, savings, insurance, and business development services (BDS) to its clients. BDS are non-financial services such as business training, market linkages, and information services which are provided by Microfinance Institutions (MFIs) to its clients. BDS help owner managers improve sales and profits and enable MFIs to achieve higher loan repayment rates and higher potential for client retention. The counsellors of MFIs provide BDS to owner managers of micro enterprises. This study focuses on the co-production of BDS where a counsellor of MFI and the owner manager of a microenterprise engage in the co-production of services. For a successful co-production, the client (i.e. owner manager in this study) has to a play an active role by exercising three client factors, namely ability, clarity of the role, and motivation. Thus, the objective of this study is to explore how the client/owner manager motivation (i.e. willingness) affects the co-production of BDS in counselling within a microfinance setting. A multiple case study method was used to conduct the present study by choosing six Sri Lankan MFIs as cases, where the selection of cases and respondents was based on a purposive sampling method. A counsellor and an owner manager representing each MFI were interviewed for data collection and thematic analysis was used to analyse the data. The findings show that economic factors, sanctions, and contextual factors influence the willingness of owner managers to co-produce BDS with counsellors of microfinance institutions (MFIs). The findings contribute to knowledge and practice domains related to microfinance.
\end{abstract}

Keywords: willingness, motivation, business counselling, co-production, microfinance

JEL Classification: M10.

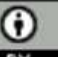

This work is licensed under a Creative Commons Attribution 4.0 International License

Cite as: Abeysekera, R. (2020). The Nexus between Co-production and Willingness: Business Counselling in the Microfinance Sector. Financial Markets, Institutions and Risks, 4(2), 43-51. http://doi.org/10.21272/fmir.4(2).43-51.2020.

\section{Introduction}

Microfinance is the provision of unsecured small loans and other services such as savings, insurance and Business Development Services (BDS) to individuals with low income. (Khavul, 2010; ADB, 1997). Therein, MFIs are mainly present in developing countries where 2.8 billion people fall below the poverty line of living on less than $\$ 2$ a day (Easterly, 2006, p.165; World Bank, 2014). Microfinance Institutions (MFIs) provide these services using innovative techniques such as setting up group lending facilities, gradually increasing loan sizes with no or little collateral, and imposing pre loan savings requirements (CGAP, 2011; Khavul, 2010; ADB, 1997). MFIs believe that clients/owner managers who obtain the services make use of them to start and expand businesses (Khavul, 2010; World Bank, 2014). This study focuses on the willingness of owner of managers of micro enterprises to obtain BDS provided by MFIs.BDS are non-financial services such as management training, vocational training, marketing assistance, and access to technology which are provided to entrepreneurs by MFIs (Khavul, 2010; Sievers and Vandenberg, 2007). The counsellors attached to MFIs provide BDS to owner managers via counselling. For an effective counselling intervention, it is understood that there should be co-production between the counsellors and the clients. In this paper, co-production is defined as "engaging customers as active participants in the organisation's work" (Lengnick-Hall et al., 2000, p. 359). Three customer/client factors are key to effective co-production: perceived clarity of the task/role; ability or competence; and motivation (Meuter et al., 2005; Bettencourt et al., 2002; Lengnick-Hall et al., 
2000; Lengnick-Hall, 1996; Lovelock and Young, 1979). The present paper focuses only on the motivation or willingness on the part of the client in co-production as it is considered that the owner manager's willingness is vital for an effective counselling intervention. While literature on co-production (Alford, 2009, 2014; Etgar, 2008; Rice, 2002; Sharp, 1978) discusses how willingness of customers affect co-production, there is no study particularly relating to BDS conducted in microfinance sector, on how the owner manager's willingness influence co-production. In this light, a related research question is what are the owner manager factors affecting the willingness to co-produce BDS with counsellors? The remainder of the paper is organised as follows. The first section presents extant literature on the Sri Lankan microfinance sector, and discusses how co-production is carried out when counsellors of MFIs provide BDS to owner managers. The research methodology is explained in the second section, following the presentation of the findings in the third section. The final section of the paper presents the discussion and outlines the conclusions and implications of the study. In this paper the definition of owner manager, client and customer are used interchangeably.

\section{Literature Review}

\subsection{Microfinance in Sri Lanka}

Sri Lanka is an island in South Asia and is a lower-middle income country. Sri Lanka's holds claim to a microfinance sector which has a long history that can be traced back to 1900s. (GTZProMis, 2010a; Tilakaratne et al., 2005). There are more than 10,000 branches under main players of MFIs, covering the entire island and thereby achieving a higher outreach. MFIs in Sri Lanka represent different legal entities such as government, non-governmental organisations (NGOs), bank, non-bank, and cooperative rural bank/ societies (GTZProMis, 2010). The government of Sri Lanka has understood the importance of microfinance to alleviate poverty through livelihood development and it has been directly involved in promoting microfinance in the country (NEDA, 2013; Tilakaratne et al., 2009). MFIs in Sri Lanka provide many services to its clients including credit, savings, and insurance facilities as well as BDS (Abeysekera, 2016; NEDA, 2013; Tilakaratne et al., 2009). The counsellors attached to MFIs provide these services to the owner managers. This study focuses on how counsellors provide BDS to owner managers through process of counselling.

\subsection{BDS via counselling}

Counselling refers to advice given by counsellors of MFIs to aspiring, embryonic and established businesses on how to exploit growth opportunities and how to manage the many problems which challenge the growth of a small firm (Johnson, 1991). Studies show that the counsellors of MFIs provide BDS to owner managers through one-to-one counselling and group counselling methods (Abeysekera, 2016). In one-to-one counselling, the counsellor provides counselling to one person whereas in group counselling, the counsellor provides counselling to group of people at the same time (Abeysekera, 2016; Abeysekera et al, 2015). Counsellors of MFIs assist owner managers to absorb capabilities, to evaluate their present situation, to evaluate the pros and cons of alternatives, and to ultimately make an informed decision.

In this respect, the type of lending methodology (i.e. group, individual) used by MFIs could also influence counselling. MFIs use group lending and/or individual lending to provide its services. In a group lending scenario, MFIs form groups of clients in which a group could have 7 to 10 clients. These groups hold meetings on regular basis and counsellors/loan officers attend these meetings to provide services including counselling. In contrast, in individual lending settings, MFIs provide services including counselling directly to the client as there are no groups (Xu et al, 2019; Khavul, 2010; Denotes and Alexandar, 2004). Thus, it is believed that counselling takes place frequently in group lending settings where counsellors and clients meet at regular intervals, in comparison compared to individual lending settings where meetings are less regular. Counsellors provide counselling to owner managers and potential owner managers at various locations including at MFI branches, in the field, at owner managers' homes, and places such as schools, temples, community halls (Abeysekera, 2016).

MFIs believe that by providing BDS, the owner managers could achieve more sales, profits and expand their businesses owing to the improved business knowledge and skills of owner managers. The provision of BDS is also advantageous as MFIs could achieve higher loan repayments rates given that owner managers tend to pay back the loans with improved business performance (Sievers and Vandenberg, 2007). Literature (Meuter et al., 2005; Bettencourt et al., 2002; Lengnick-Hall et al., 2000) shows that the effectiveness of a service such as counselling is dependent on the co-production between the counsellor and the owner manager/client. 
Therefore, in co-production, the active participation of the owner manager/client in the service production is vital.

\subsection{Co-production}

The theory of co-production was first introduced to the world in a workshop on Political Theory and Policy Analysis conducted at Indiana University in United States of America in 1973. Originally, the concept of coproduction related to clients' or citizens' direct involvement in production, and there onwards this concept caught the attention of public administration scholars in United States in 1970s and 1980s. (Abeysekera, 2015; Parks et al., 1981). Co-production was initially used in industrial and service markets (Fitzsimmons, 1985). In 1990s it was used by the consumer market wherein the customer took an active role in production process (Williams and Caley, 2020; Firat and Shultz, 1997; Firat et al., 1995; Firat and Venkatesh, 1993, 1995; Firat, 1991). In recent times, the work on co-creation and service dominant logic of marketing literature drive the concept of co-production (Vargo and Lusch, 2004). Until recently, the logic was that value creation happens with the final product (Goods dominant logic, G-D). However, Vargo and Lush (2004) argue that value is defined and created mainly by the customer and thus, the customer plays a major role in the co-production process ( service dominant logic, S-D). Service logic expounds on the collaboration of customer in coproduction and explains the benefits of co-production such as increased productivity, reduced risk, and the facilitation of customised service offerings. For this study, it is considered that the owner manager or customer plays a vital role in co-production of BDS via counselling and hence, co-production is defined as "engaging customers as active participants in the organisation's work" (Lengnick-Hall et al., 2000, p. 359). The studies show that perceived clarity of the role, competence, and motivation/willingness are customer related factors that are key to co-production (Meuter et al., 2005; Bettencourt et al., 2002; Lengnick-Hall et al., 2000; Lengnick-Hall, 1996; Lovelock and Young, 1979). In this study, however, the owner manager willingness in co-production is investigated and the following section describes the customer/owner manager willingness in co-production.

\subsection{Willingness in co-production}

In counselling, customers/ owner mangers' willingness determines their contribution in co-production, in terms of both spending time and money, and the kind of relationship they establish with the counsellor of an MFI. For example, clients may spend time, are pleasant with the counsellor, and provide information to him because of the willingness to co-produce. Alford (2014) and Sharp(1978) elucidate that clients are willing to coproduce due to material gains, being able to associate with others, and due to sanctions imposed by the service provider. Etgar (2008) proposes that customer's willingness to co-produce is dependent on a number of factors such as product related factors (e.g. product quality), consumer related factors (e.g. consumer skills), situational factors (e.g. customer -contact staff interaction), economic drives (e.g. economic benefits), psychological drives (e.g. enjoyment), social drives (e.g. self-esteem), and extrinsic values (e.g. autonomy).

Rice (2002) identified that client willingness is needed to co-produce business assistance in business incubators. Schayek and Dvir (2009) s' study on public assistance programs in Israel found that willingness of entrepreneurs is important in counselling. Further, the literature on small businesses and microfinance reveal that the managers are willing to obtain services such as counselling and training due to the economic benefits it provides such as improved sales and profits. Furthermore, the literature shows that clients/owner mangers are motivated to co-produce as a result of contextual factors such as location and timing of the intervention (i.e. counselling) and the sanctions imposed (e.g. counselling is compulsory). The study done by Karlan and Valdivia (2006) on business training offered by a Peruvian MFI shows that clients dropped out from training as they did not participate willingly. Further, ADEMCOL (2001)'s study on business training given in Columbia shows that the clients did not utilize the knowledge gained at the business training as they took part in the same unwillingly. Hence, willingness in co-production is very important in effective service production like counselling.

\section{Methodology}

Exploring the factors influencing willingness to co-produce in business counselling is a contemporary phenomenon which must be examined in the real-life context. Thus, the case study method is the suitable method for this study as it helps identify the rich insights and provides a holistic understanding of the phenomena (Yin, 2009). Since the multiple case study method provides theoretical generalisation in contrast to the statistical generalisation which is the goal of this study, multiple case study method was chosen for this study. Six cases (i.e. MFIs) were selected for this study and this number coincides with Eisenhardt's (1989)'s 
suggestion of four to ten case studies to accomplish theoretical saturation. Unit of analysis for the study was individuals representing MFIs and microenterprises. Six cases were selected for the study by using purposive sampling. MFIs representing government, banks, non-banks, NGOs, public and private companies were selected for the study. Further, MFIs were selected based on the lending methodology (i.e. group lending and individual lending). It is assumed that willingness to counselling could be influenced by the type of the MFI and the type of lending methodology. A counsellor and an owner manager from each MFI were selected for in-depth interviews. The selections of counsellors and owner managers were made after consulting with MFIs. Thus, 12 in-depth interviews were conducted for the purpose of data collection for the study.

The profiles of the MFIs selected for the study are given below in the Table 1.

Table 1. Types of Mfis Selected for the Study

\begin{tabular}{|l|l|l|}
\hline \multicolumn{1}{|c|}{ MFIs } & \multicolumn{1}{|c|}{ Type of MFI } & \multicolumn{1}{c|}{ Lending methodology } \\
\hline MFI-1 & Public company & Group \\
\hline MFI-2 & Non-Bank & Group \\
\hline MFI-3 & Private bank & Individual \\
\hline MFI-4 & Private company & Group \\
\hline MFI-5 & NGO & Group \\
\hline MFI-6 & Government & Group \\
\hline
\end{tabular}

Source: Compiled by the author.

Before embarking on the data collection, a pilot study was carried out with a counsellor and an owner manager to refine the semi-structured questionnaire used for in-depth interviews. The interviews were conducted visiting counsellors at MFI branch offices and owner managers at their business premises. The average duration for the 12 interviews conducted ranged from 45 to 60 minutes. The interviews were conducted in the language mediums of both Sinhalese and English. To meet ethical considerations, informed consent was taken from each interviewee. All the interviews were tape-recorded and then transcribed. Transcriptions were used to perform thematic analysis. Data analysis techniques and strategies such as pattern matching and cross synthesis as prescribed by Yin (2009) were used to analyse data. By using multiple data sources, pattern matching and multiple cases, the construct, internal and external validity were achieved. Furthermore, by following the case study protocol, reliability was achieved. The thematic analysis of data was based on the main research question: what are the owner manager factors affecting willingness to co-produce BDS with counsellors?

\section{Findings}

The findings reveal that the owner managers are willing to engage in co-production with counsellors due to motivational factors (i.e. economic benefits, sense of ownership, relationship with counsellors), sanctions (i.e. regular attendance of owner managers to group meetings), and contextual factors (i.e. time related, product related, location related, awareness and socialisation related).

The following section explains each of these factors, with relevant quotations.

Motivational factors - The following quotation shows how economic benefits relating to motivational factors influence the willingness of owner managers to participate in co-production.

The owner manager 1 of MFI-1 explained that,

"I was able to improve the sales and profits of my furniture business due to advice I got from our counsellor. So, I always want to work with him."

The owner managers are willing to obtain counselling and co-produce if they have contributed to product design, resulting in a sense of ownership. Thus, it was found that a sense of ownership was important in coproduction. This was evidenced from the following excerpt.

The counsellor of MFI-1 stated that,

"It is very important to consider clients' views when designing BDS. They should own the idea, and only then will they give their willingness and commitment to BDS. Some projects failed because they were not clients' projects." 
The findings also show that the owner manager's relationship with the counsellor affects the co-production. The following statements substantiated this.

The owner manager-2 of MFI-2 stated that,

"Our counsellor is a friendly person. I always like to interact with him."

The counsellor of MFI-5 expressed that,

"Our clients are willing to get our services if we maintain a good relationship with them"

Sanctions - The findings reveal that sanctions imposed by MFIs could either motivate or demotivate the clients to co-produce. MFIs insist that clients attend group meetings regularly (i.e. sanction) as a prerequisite to obtain its services (i.e. credit, BDS). The following statement indicates how group meetings motivate the clients to engage in co-production.

The owner manager -1 of MFI- 4 said that,

"I love to attend the meetings regularly. I always wait impatiently until the meeting comes to attend it. We can meet our friends and MFI officers, who provide us with counselling at the meetings."

In contrast, some clients said that the regular group meetings being a pre-requisite factor prevented them from obtaining counselling. This was evident from the following quotation.

The owner manager-2 of MFI-2 explained that,

"Earlier I used to attend group and society meetings regularly, but now I cannot attend regularly since I am busy with business."

The owner manager mentioned that she was not happy with the pre-requisite and wished that she could attend meetings to obtain counselling at her will. Group meetings can be seen in MFIs which use group lending methodology and hence, the type of lending methodology could influence the willingness of owner managers to co-produce.

Contextual factors - The data shows that a number of contextual factors such as time, product related factors, location, and social mobilisation programmes influence the willingness of the clients to engage in counselling (i.e. co-production). The findings show that the owner manager is willing to participate in counselling if the time of counselling is convenient to him. Time is very precious for owner managers as they are busy with business activities and household chores. Hence, they like to meet the counsellor either in the morning or evening.

The owner manager -1 of MFI-5 declared that,

"We prefer it if the counsellor visits us in the morning or evening. Generally, we are busy during lunch time."

The counsellors who were interviewed also were in agreement with the owner managers about the time of counselling.

The counsellor of MFI-4 stated that,

"Morning and evening sessions are the good times to meet the client. Sometimes the client may be busy with the business and household chores between 11 am and 4pm. So, I always visit clients either in the morning or evening."

The findings further show that type of guidance (i.e. product-related) given through the counselling motivated them to engage in the process. For example, they were willing to hear about market linkages through counselling.

The following quotations support this.

The owner manager-2 of MFI-4 stated that,

"I produce ornaments to sell using traditional materials. Our MFI holds a trade fair once a month for us to sell our products. But this is not enough. If the MFI can provide us more marketing links, then we can sell our products."

The counsellor of MFI-3 stated that, 
"Our clients like to hear some our products more. For example, they like us helping them to sell their products"

On a similar note, owner managers also mentioned that they were willing to take part in counselling sessions if the location is convenient to them. If the location is convenient, they could discuss their problems privately and need not to bother about transportation cost and dress code. This could be corroborated from the following excerpts.

The counsellor of MFI-1 stated that,

"I provide counselling at cluster meetings, my office and at clients' homes. When we visit clients at home, then they do not have to worry about their dress code nor transportation. If they are to meet me at my office they have to wear a proper dress and spend money on transportation"

The counsellor of MFI-3 indicated that,

"Clients do not like to discuss certain business matters at the bank branch (office). They always like to discuss them at their homes. So, we visit them at their homes/business premises."

The owner manager-1 of MFI-1 declared that,

"We get counselling at cluster meetings held at nearby temples or the counsellor visits us. It is convenient for us."

The findings from cases reveal that social mobilisation programmes offered by MFIs inspire owner managers to engage in counselling. MFIs use social mobilisation programmes to educate clients about financial literacy, its products, and form groups with members who are willing to obtain services of MFIs. The following quotations give examples for this.

The counsellor of MFI-5 stated that,

"Social mobilisation programmes will enhance the client's engagement in counselling and training. The client who has undergone the social mobilisation process knows the importance of counselling and training because he has already seen a change in him."

The owner manager-1 of MFI-5 emphasised the importance of the social mobilisation programme thusly;

"The social mobilisation programme has helped us. I was in a group of five members. We learnt how to work in a group. Besides, we were given knowledge on household and business management, savings and some other topics in this programme. This programme really motivated us to work with the counsellors and trainers later."

It was found that only MFI-2, MFI-4, MFI-5 and MFI-6 have social mobilisation programmes. Hence, the owner of managers of these MFIs were more willing to engage in counselling because of these programmes. Further, it was found that social mobilisation programmes were often offered by MFIs who practiced group lending methodology. The type of MFI did not directly affect owner manager willingness to engage in counselling. However, it influences indirectly as the type of MFI could determine the lending methodology and product portfolio it offers. For example, government MFIs use group lending methodology as opposed to a private bank. Further, it was found that some MFIs, for example, bank-MFIs did not provide many products compared to government MFIs. This could be due to the profit motives of MFIs. Product portfolio with a higher number of products could enhance the willingness of owner managers to engage in counselling (i.e. product related factors).

\section{Discussion, conclusions and implications}

The findings show that motivational factors, sanctions, and contextual factors influence the willingness of owner managers to engage in counselling (i.e. co-production). The following table shows how the findings are consistent with the previous literature.

Table 2. Factors affecting owner managers' willingness and supporting literature

\begin{tabular}{|l|l|}
\hline Study findings on factors that affect owner manager willingness & Relevant literature \\
\hline $\begin{array}{l}\text { Economic benefits gained by owner managers engaging in counselling; e.g. better } \\
\text { sales, profits, and knowledge (motivators) }\end{array}$ & $\begin{array}{l}\text { Material gains (Alford 2009, 2014) and Sharp } \\
\text { (1978); economic drives (Etgar, 2008) }\end{array}$ \\
\hline $\begin{array}{l}\text { Sense of ownership (by participating in the BDS design, an owner manager is } \\
\text { motivated to co-produce in BDS) (motivators) }\end{array}$ & Psychological drives (Etgar, 2008) \\
\hline $\begin{array}{l}\text { Relationship between counsellor and owner manager; the relationship with the } \\
\text { counsellor will motivate the owner manager to co-produce in BDS (motivators) }\end{array}$ & Situational factors (Etgar, 2008) \\
\hline
\end{tabular}


Table 2 (cont.). Factors affecting owner managers' willingness and supporting literature

\begin{tabular}{|l|l|}
\hline $\begin{array}{l}\text { Owner managers' compulsory attendance at group meetings either motivates or } \\
\text { de-motivates their counselling (sanctions) }\end{array}$ & Sanctions (Alford, 2009, 2014) \\
\hline $\begin{array}{l}\text { Location, time, social mobilisation programmes, group and product-related } \\
\text { factors motivate owner managers to engage in counselling (contextual factors) }\end{array}$ & $\begin{array}{l}\text { Contextual elements (Pestoff, 2012; Eijk and Steen, } \\
\text { 2014) }\end{array}$ \\
\hline
\end{tabular}

Source: author's compilation.

As can be seen from Table 2, the findings relating to motivational factors (i.e. economic benefits, sense of ownership and interpersonal relationships) that improve the willingness of owner managers to co-produce with counsellors are consistent with the work of Alford (2014), Etgar (2008) and Sharp (1978) on co-production.

The findings reveal that group meetings regarded as a sanction could either motivate or demotivate the clients to engage in counselling. This finding is in line with Alford $(2009,2014)$ 's work in which he stresses that sanctions imposed could motivate and sometimes demotivate the clients to engage in co-production.

The literature on co-production also reveals that contextual factors can enhance the willingness of clients to co-produce (Pestoff, 2012; Eijk and Steen, 2014) and therefore the findings related to the factors that improve the willingness of owner managers to co-produce including factors of time and location, are consistent with the extant literature.

However, although the extant literature on co-production discusses the factors affecting willingness, there are no empirical studies done to find out factors affecting the willingness of the client in co-production and thus, this study fills this gap. Furthermore, the present study shows that the type of MFI and the type of lending method could influence the willingness of owner managers to engage in co-production.

Based on these findings, MFIs could improve the effectiveness of counselling by educating the counsellors to highlight the economic benefits in counselling sessions, to get clients' involvement in product design, and to maintain better relationships with the clients. Further, MFIs need to be careful about the imposition of sanctions like making group meeting compulsory as it could sometimes prevent the clients from obtaining counselling. Moreover, the counsellors must consider the convenience related to factors such as time and location, as well as product related factors that are useful to better engage the clients in counselling. It should also be highlighted that social mobilisation programmes offered by certain MFIs motivate the clients to engage in counselling, and thus conducting such programmes are vital. According to the study's findings, the type of MFI and lending methodology could have a bearing on the counselling, and thereby on the willingness of owner managers. Hence, MFIs which are profit oriented and use individual lending methods, need to think about counselling interventions and innovative strategies to improve the willingness of owner managers to engage in counselling. This research, therefore, contributes to the knowledge domains embedded in co-production theory, counselling and microfinance sectors. Further, it also contributes to the practitioners in microfinance sector. Moreover, future research could be carried out in different sectors and interventions in order to identify the factors affecting willingness in co-production

\section{References}

1. Abeysekera, R., (2016). Enhancing entrepreneurship in Sri Lanka: the provision of business development services (BDS) by microfinance institutions to support the self-sufficiency of microenterprises" (Doctoral dissertation, Bournemouth University). Available from: http://eprints.bournemouth.ac.uk/24721/ (Accessed 20 May, 2020).

2. Abeysekera, R. (2015). Concepts and implications of theory of co-production, Colombo Business Journal, 6(2), 22-38. Available from: http://220.247.247.85:8081/handle/123456789/8003 (Accessed 20 May, 2020).

3. Abeysekera, R., Patton, D. and Mullineux, A. (2015). Co-production in Business Counselling in Microfinance Setting: A conceptual approach. Journal of Enterprising Culture, 23(03), 299-319. https://doi.org/10.1142/S0218495815500107

4. ADB. (1997). Microenterprise development: Not by credit alone. Manila: Asian Development Bank.

5. Ademcol. (2001). Asociacio'n para el Desarrollo Microempresarial Colombiano and Women's Opportunity Fund: Bundling microfinance and business development services. A case study from Ademcol in Colombia, Microenterprise Best Practices. Washington, DC: United States Agency for International Development.

6. Alford, J. (2009). Engaging private sector clients from service delivery to co-production. Basingstoke: Palgrave. Available from: https://www.researchgate.net/publication/ 260249500 Alford JL 
2009 Engaging_Public Sector $\quad$ Clients_From_Service-Delivery to_Co-production_Palgrave Macmillan Basingstoke Hampshire 272 pages ISBN 978-0-230-22376-9

7. Alford, J. (2014). The multiple facets of co-production: building on the work of Elinor Ostrom. Public Management Review, 16(3), 299-316.u. https://doi.org/10.1080/14719037.2013.806578

8. Begum, H., Alam, A.F., Mia, M.A., Bhuiyan, F. and Ghani, A.B.A. (2019). Development of Islamic microfinance: a sustainable poverty reduction approach. Journal of Economic and Administrative Sciences. https://doi.org/10.1108/JEAS-01-2018-0007

9. Bettencourt, L. A., Ostrom, A. L., Brown, S. W. and Roundtree, R. I. (2002). Client co-production in knowledge-intensive business services. California Management Review, 44 (4), 100-128. https://doi.org/10.2307\%2F41166145

10. CGAP. (2011). Advancing financial access to world poor [online]. Washington: Consultative group to assist the poor. Available from: http://www.cgap.org/p/site/c/about/ [Accessed 20 April 2020].

11. Denotes, V. and Alexander, S. K., 2004. The individual micro-lending contract: is it a better design than joint-liability? Evidence from Georgia. Economic Systems, 28, 155-176. https://doi.org/10.1016/j.ecosys.2004.03.006

12. Easterly, W. (2006). The white man's burden: Why the West's efforts to aid the rest have done so much ill and so little good. New York: Penguin Press.

13. Eijk, C.J.A. V. and Steen, T. P. S. (2014). Why people co-produce: analysing citizens' perceptions on coplanning engagement in health care services. Public management review. 16(3), 358-382. https://doi.org/10.1080/14719037.2013.841458

14. Eisenhardt, K. M. (1989). Building theories from case-study research. Academy of management review, 14 (4), 532-550.

15. Etgar, M. (2008). A descriptive model of the consumer co-production process. Journal of the academy of marketing science, 36 (1), 97-108. https://doi.org/10.1007/s11747-007-0061-1

16. Firat A. F. and Shultz C.J. (1997). From segmentation to fragmentation. European journal of marketing, 31 (3/4), 183-207. https://doi.org/10.1108/EUM0000000004321

17. Firat A. F., Dholakia N. and Venkatesh, A. (1995). Marketing in postmodern world.European journal of marketing, 29 (1), 40-56. https://doi.org/10.1108/03090569510075334

18. Firat, A. F. and Venkatesh, A. (1993). Post modernity: the age of marketing. International journal of research in marketing, 10 (3), 227-249. https://doi.org/10.1016/0167-8116(93)90009-N

19. Firat, A. F. and Venkatesh, A. (1995). Liberatory postmodernism and the re-enchantment of consumption. Journal of consumer Research, 22(3), 239-267. https://doi.org/10.1086/209448

20. Firat, A. F. (1991).The consumer in postmodernity. Advances in consumer research. 18(1), 70-76. Available from: https://www.acrwebsite.org/volumes/7141/volumes/v18/NA-18

21. Fitzsimmons, J.A. (1985). Consumer participation and productivity in service operations. Interfaces, 15(3), 60-67. https://doi.org/10.1287/inte.15.3.60

22. GTZ ProMiS. (2010). Micro Finance Industry Report. Sri Lanka: GTZ ProMiS and The Banking With the Poor Network. Available from: https://www.findevgateway.org/sites/default/files/publications/files/mfgen-paper-microfinance-industry-report-sri-lanka-2010.pdf

23. Karlan, D. and Valdivia, M. (2006). Teaching Entrepreneurship: Impact of Business Training on Micro Finance Clients and Institutions. Economic Growth Centre Discussion Paper, 941, Yale University: Economic Growth Centre. Available from: http://www.econ.yale.edu/growth pdf/cdp941.pdf (Accessed 10 May, 2020)

24. Khavul, S. (2010). Microfinance: Creating Opportunities for the Poor? Academy of management perspectives, 24 (3), 58-72. https://doi.org/10.5465/amp.24.3.58.

25. Lengnick-Hall, C. A. (1996). Customer contributions to quality: A different view of the customer-oriented firm, Academy of management review, 21 (3), 791- 824. https://doi.org/10.5465/amr.1996.9702100315

26. Lengnick-Hall, C. A., Claycomb, V. and Inks, L. W. (2000). From recipient to contributor: examining customer roles and experienced outcomes. European Journal of Marketing, 34 (3/4), 359-383. https://doi.org/10.1108/03090560010311902

27. Lovelock, C. H. and Young, R. F. (1979). Look to consumers to increase productivity. Harvard business review, 57 (3), 168-178. Available from: https://hbr.org/1979/05/look-to-consumers-to-increaseproductivity 
28. Meuter, M. L., Bitner, M. J., Ostrom, A. L. and Brown, S. W. (2005). Choosing among alternative service delivery modes: An investigation of customer trial of self-service technologies. Journal of marketing, 69 (2), 61-83. https://doi.org/10.1509\%2Fjmkg.69.2.61.60759

29. NEDA. (2013). Micro enterprise policy paper [Online]. Sri Lanka: National Enterprise Development Authority. Available from: http://www.industry.gov.lk/web/images/pdf/gg.pdf

30. Parks, R. B., Baker, P. C., Kiser, L., Oakerson, R., Ostrom, E., Ostrom, V., Percy, S. L., Vandivort, M. B., Whitaker, G. P. and Wilson, R. (1981. Consumers as coproducers of public services: some economic and institutional considerations. Policy studies journal, 9 (7), 1001-1011. https://doi.org/10.1111/j.15410072.1981.tb01208.x

31. Pestoff, V. (2012). Co-production and third sector social services in Europe. In: Pestoff, V., Brandsen, T. and Verschuere, B., eds. New public governance, the third sector and co-production. New York: Routledge, 13-34.

32. Rice, M. P. (2002). Co-production of business assistance in business incubators - An exploratory study. Journal of business venturing, 17 (2), 163-187. https://doi.org/10.1016/S0883-9026(00)00055-0

33. Schayek, K. and Dvir, D. (2009). Measuring the effect of public assistance programs on small businesses' performance. Journal of general management, 35 (2), 3-20. https://doi.org/10.1177 $\% 2 \mathrm{~F} 030630700903500202$

34. Sharp, E. (1978). Citizen organizations and participation in law enforcement advocacy and coproduction: The role of incentives. Thesis $(\mathrm{PhD})$. University of North Carolina at Chapel Hill.

35. Sievers, M., and Vandenberg, P. (2007). Synergies through linkages: who benefits from linking microfinance and business development services? World development, 35 (8), 1341-1358. https://doi.org/10.1016/j.worlddev.2007.04.002

36. Tilakaratne, G., Galappattige, A. and Perera R. (2009). Promoting empowerment through microfinance in Sri Lanka, economic and political empowerment of the poor- Sri Lanka. Sri Lanka: Centre for policy dialogue, South Asia Centre for policy studies. Available from: http://www.ips.lk/economic-and-politicalempowerment-of-the-poor-promoting-empowerment-through-microfinance-programmes/

37. Tilakaratne, G., Wickramsinghe, U. and Thusitha, K. (2005). Micro finance in Sri Lanka: a household level analysis of outreach and impact on poverty. Sri Lanka: Institute of Policy Studies of Sri Lanka. Available from: http://www.pep-net.org/sites/pep-net.org/files/typo3doc/pdf/files_events/4th_colombo/ Ganga.pdf (Accessed 21 May, 2020)

38. Vargo S. L. and Lusch R. F. (2004). Evolving to a new dominant logic for marketing. Journal of marketing, 68 (1), 1-17. https://doi.org/10.1509\%2Fjmkg.68.1.1.24036

39. Williams, S.J. and Caley, L. (2020). Defining Co-production. In Improving Healthcare Services (pp. 3954). Palgrave Pivot, Cham. https://doi.org/10.1007/978-3-030-36498-4 9

40. World Bank. (2014). Poverty Review [Online]. Washington DC: World Bank. Available from: http://www.worldbank.org/en/topic/poverty/overview [accessed 19 May, 2020].

41. Xu, Y., Cheng, W. and Zhang, L. (2019). Switching from group lending to individual lending: the experience at China's largest microfinance institution. Emerging Markets Finance and Trade, 1-18. https://doi.org/10.1080/1540496X.2019.1636228

42. Yin, R. K. (2009). Case-study research: Design and methods 4th edition ed. London: Sage. Available from: https://journals.nipissingu.ca/index.php/cjar/article/view/73 